\title{
Isolation of High-Molecular-Weight DNA Using Organic Solvents
}

\author{
Michael R. Green and Joseph Sambrook
}

Perhaps the most basic of all procedures in molecular cloning is the purification of nucleic acids. The key step, the removal of proteins, can often be performed simply by extracting aqueous solutions of nucleic acids with phenol:chloroform and chloroform.

\section{MATERIALS}

It is essential that you consult the appropriate Material Safety Data Sheets and your institution's Environmental Health and Safety Office for proper handling of equipment and hazardous materials used in this protocol.

RECIPES: Please see the end of this protocol for recipes indicated by $<R>$. Additional recipes can be found online at http://cshprotocols.cshlp.org/site/recipes.

\section{Reagents}

\section{Chloroform}

DNA sample

Ethanol (95\%, 70\%)

Ether (optional; see Step 7)

Phenol:chloroform $(1: 1, \mathrm{v} / \mathrm{v})$ (see Box 1 and Discussion)

Phenol-chloroform extractions efficiently inactivate and remove enzymes that are used in one step of a cloning operation before proceeding to the next. However, additional measures are required when nucleic acids are purified from complex mixtures of molecules such as cell lysates. In these cases, it is usual to remove most of the protein by digestion with proteolytic enzymes such as Pronase or proteinase $K$ (Table 1), which are active against a broad spectrum of native proteins, before extracting with organic solvents.

Salt solution (10 M ammonium acetate, $8 \mathrm{~m} \mathrm{LiCl,} 5 \mathrm{~m} \mathrm{NaCl}$, or $3 \mathrm{~m}$ sodium acetate) See the Discussion in Protocol: Precipitation of DNA with Ethanol (Green and Sambrook 2016) for details.

TE buffer, $10 \times<\mathrm{R}>(\mathrm{pH} 7.8)$ (optional; see Step 4)

Dilute stock solution before use.

Equipment

Polypropylene tubes

1. Transfer the sample to a polypropylene tube, and add an equal volume of phenol:chloroform.

From the Molecular Cloning collection, edited by Michael R. Green and Joseph Sambrook.

(C) 2017 Cold Spring Harbor Laboratory Press

Cite this protocol as Cold Spring Harb Protoc; doi:10.1101/pdb.prot093450 


\section{BOX 1. HISTORICAL FOOTNOTE ON PHENOL $\left(\mathrm{C}_{6} \mathrm{H}_{6} \mathrm{O}\right.$, F.W. = 94.11)}

Until the mid-1950s, the standard method of purifying DNA involved stripping protein from the nucleic acid with detergent and strong salt solutions (e.g., perchlorate). Final deproteinization was achieved by several extractions with chloroform laced with isoamyl alcohol (Sevag 1934; Sevag et al. 1938). The first reported use of phenol to purify nucleic acids was published by Kirby (1956), who was aware of the power of phenol to extract proteins from aqueous solution (Grassmann and Deffner 1953). In his initial paper, Kirby showed that extraction of homogenates of mammalian tissue with a two-phase phenol- $\mathrm{H}_{2} \mathrm{O}$ mixture at room temperature led to partitioning of RNA into the aqueous layer. DNA remained associated with protein at the interface. Kirby quickly realized that replacement of $\mathrm{H}_{2} \mathrm{O}$ by solutions of anionic salts released both RNA and DNA into the aqueous phase (Kirby 1957; for review, see Kirby 1964). Although the use of anionic salts to release proteins from DNA was quickly abandoned in favor of strong anionic detergents such as SDS, Kirby's original description of phenol extraction forms the basis of many purification methods in common use today. The function of the phenol is probably the same as that of a protein solvent: It extracts protein that has been dissociated from nucleic acids by anionic salts or detergents. So efficient is this process that pure preparations of nucleic acid are obtained after just two or three extractions with phenol.

Purified phenol has a specific gravity of 1.07 and therefore forms the lower phase when mixed with $\mathrm{H}_{2} \mathrm{O}$. However, the organic and aqueous phases may be difficult to separate or may invert when phenol is used to extract protein from aqueous solutions containing high concentrations of solutes. This problem is largely alleviated when a 50:50 mixture of phenol:chloroform is used, because the higher density of chloroform (1.47) ensures separation of the two phases. Denatured proteins collect at the interface between the two phases, while lipids partition efficiently into the organic layer. Isoamyl alcohol is often added to the phenol:chloroform mixture to reduce foaming.

Pure phenol is supplied as a white crystalline mass (m.p. $43^{\circ} \mathrm{C}$ ). However, upon exposure to air and light, phenol is prone to redden, a process that is accelerated by alkalinity. Crystalline phenol is not recommended because it must be redistilled at $182^{\circ} \mathrm{C}$ to remove oxidation products such as quinones that cause the breakdown of phosphodiester bonds or promote cross-linking of nucleic acids.

The liquefied form of phenol provided by many manufacturers contains $\sim 8 \% \mathrm{H}_{2} \mathrm{O}$ and can be stored frozen at $-20^{\circ} \mathrm{C}$. Liquefied phenol, if colorless, can be used in molecular cloning without redistillation. Today, only occasional batches of liquefied phenol are pink or yellow, and these should be rejected and returned to the manufacturer.

Before use, phenol must be saturated with $\mathrm{H}_{2} \mathrm{O}$ and equilibrated with Tris to a $\mathrm{pH}$ of $>7.8$ to suppress partitioning of DNA into the organic phase, which occurs at acidic $\mathrm{pH}$.

The nucleic acid will tend to partition into the organic phase if the phenol has not been adequately equilibrated to a $\mathrm{pH}$ of $7.8-8.0$.

2. Mix the contents of the tube until an emulsion forms.

The organic and aqueous phases may be mixed by vortexing when isolating small DNA molecules (<10 kb) or by gentle shaking when isolating DNA molecules of moderate size (10-30 kb). When isolating large DNA molecules ( $>30 \mathrm{~kb}$ ), the following precautions must be taken to avoid shearing.

- Mix the organic and aqueous phases by rotating the tube slowly (20 rpm) on a wheel.

- Use large-bore pipettes to transfer the DNA from one tube to another.

TABLE 1. Proteolytic enzymes

\begin{tabular}{|c|c|c|c|c|c|c|}
\hline & Stock solution & Storage temperature & Concentration in reaction & Reaction buffer & Temperature & Pretreatment \\
\hline Pronase $^{a}$ & $20 \mathrm{mg} / \mathrm{mL}$ in $\mathrm{H}_{2} \mathrm{O}$ & $-20^{\circ} \mathrm{C}$ & $1 \mathrm{mg} / \mathrm{mL}$ & $\begin{array}{l}0.01 \mathrm{~m} \text { Tris-Cl }(\mathrm{pH} 7.8) \\
0.01 \text { m EDTA } \\
0.5 \% \text { SDS }\end{array}$ & $37^{\circ} \mathrm{C}$ & Self-digestion ${ }^{\mathrm{b}}$ \\
\hline Proteinase $\mathrm{K}$ & $20 \mathrm{mg} / \mathrm{mL}$ in $\mathrm{H}_{2} \mathrm{O}$ & $-20^{\circ} \mathrm{C}$ & $50 \mu \mathrm{g} / \mathrm{mL}$ & $\begin{array}{l}0.01 \text { м Tris-Cl }(\mathrm{pH} 7.8) \\
0.005 \text { м EDTA } \\
0.5 \% \text { SDS }\end{array}$ & $37^{\circ} \mathrm{C}-56^{\circ} \mathrm{C}$ & None required \\
\hline
\end{tabular}

${ }^{a}$ Pronase is a mixture of serine and acid proteases isolated from Streptomyces griseus.

${ }^{\mathrm{b}}$ Self-digestion eliminates contamination with DNase and RNase. Self-digested pronase is prepared by dissolving powdered pronase in $10 \mathrm{~mm}$ Tris- $\mathrm{Cl}$ ( $\mathrm{pH} 7.5$ ), $10 \mathrm{~mm}$ $\mathrm{NaCl}$ to a final concentration of $20 \mathrm{mg} / \mathrm{mL}$ and incubating for $1 \mathrm{~h}$ at $37^{\circ} \mathrm{C}$. Store the self-digested pronase in small aliquots at $-20^{\circ} \mathrm{C}$ in tightly capped tubes. 
M.R. Green and J. Sambrook

3. Centrifuge the mixture at $80 \%$ of the maximum speed that the tubes can bear for $1 \mathrm{~min}$ at room temperature. If the organic and aqueous phases are not well separated, centrifuge again for a longer time.

Normally, the aqueous phase forms the upper phase. However, if the aqueous phase is dense because of salt $(>0.5 \mathrm{~m})$ or sucrose $(>10 \%)$, it will form the lower phase. The organic phase is easily identifiable because of the yellow color contributed by the 8-hydroxyquinoline that is added to phenol during equilibration.

4. Use a pipette to transfer the aqueous phase to a fresh tube. For small volumes $(<200 \mu \mathrm{L})$, use an automatic pipettor fitted with a disposable tip. Discard the interface and organic phase.

To achieve the best recovery, the organic phase and interface may be "back-extracted" as follows: After the first aqueous phase has been transferred as described above, add an equal volume of TE ( $\mathrm{pH} 7.8$ ) to the organic phase and interface. Mix well. Separate the phases by centrifugation as in Step 3. Combine this second aqueous phase with the first, and proceed to Step 5.

5. Repeat Steps 1-4 until no protein is visible at the interface of the organic and aqueous phases.

6. Add an equal volume of chloroform, and repeat Steps 2-4.

7. Recover the nucleic acid by standard precipitation with ethanol (see Protocol: Precipitation of DNA with Ethanol [Green and Sambrook 2016]).

Occasionally, ether is used to remove traces of chloroform from preparations of high-molecular-weight DNA.

\section{DISCUSSION}

The standard way to remove proteins from nucleic acid solutions is to extract first with phenol: chloroform (optionally containing hydroxyquinoline at $0.1 \%$ ) and then with chloroform, as described here. This procedure takes advantage of the fact that deproteinization is more efficient when two different organic solvents are used instead of one. Furthermore, although phenol denatures proteins efficiently, it does not completely inhibit RNase activity, and it is a solvent for RNA molecules that contain long tracts of poly(A) (Brawerman et al. 1972). Both of these problems can be circumvented by using a mixture of phenol:chloroform:isoamyl alcohol (25:24:1). The subsequent extraction with chloroform removes any lingering traces of phenol from the nucleic acid preparation. Extraction with ether, which was widely used for this purpose for many years, is no longer required or recommended for routine purification of DNA.

\section{RECIPE}

TE Buffer, 10x

$100 \mathrm{~mm}$ Tris- $\mathrm{Cl}$ (desired $\mathrm{pH})$

$10 \mathrm{~mm}$ EDTA (pH 8.0)

Sterilize solutions by autoclaving for $20 \mathrm{~min}$ at $15 \mathrm{psi}\left(1.05 \mathrm{~kg} / \mathrm{cm}^{2}\right)$ on liquid cycle. Store the buffer at room temperature.

\section{REFERENCES}

Brawerman G, Mendecki J, Lee SY. 1972. A procedure for the isolation of mammalian messenger ribonucleic acid. Biochemistry 11: 637-641.

Grassmann W, Deffner G. 1953. Verteilungschromatograph-isches Verhalten von Proteinen und Peptiden in phenolhaltigen Lösungsmitteln. Hoppe Zeylers Z Physiol Chem 293: 89-98.
Green MR, Sambrook J. 2016. Precipitation of DNA with ethanol. Cold Spring Harb Protoc doi: 10.1101/pdb.prot093377.

Kirby KS. 1956. A new method for the isolation of ribonucleic acids from mammalian tissues. Biochem J 64: 405-408. 
Isolation of High-Molecular-Weight DNA Using Organic Solvents

Kirby KS. 1957. A new method for the isolation of deoxyribonucleic acids: Evidence on the nature of bonds between deoxyribonucleic acid and protein. Biochem J 66: 495-504.

Kirby KS. 1964. Isolation and fractionation of nucleic acids. Prog Nucleic Acids Res Mol Biol 3: 1-31.
Sevag MG. 1934. Eine neue physikalische EntweiBungs-Methode zur Darstellung biologische wirksamer Substanzen. Biochem Z 213: 419-429.

Sevag MG, Lackmann DB, Smolens J. 1938. Isolation of components of streptococcal nucleoproteins in serologically active form. J Biol Chem 124: 425-436. 


\section{Isolation of High-Molecular-Weight DNA Using Organic Solvents}

Michael R. Green and Joseph Sambrook

Cold Spring Harb Protoc; doi: 10.1101/pdb.prot093450

\begin{tabular}{rc}
$\begin{array}{r}\text { Email Alerting } \\
\text { Service }\end{array}$ & Receive free email alerts when new articles cite this article - click here. \\
\hline $\begin{array}{r}\text { Subject } \\
\text { Categories }\end{array}$ & $\begin{array}{c}\text { Browse articles on similar topics from Cold Spring Harbor Protocols. } \\
\text { DNA Purification (160 articles) } \\
\text { Genomic DNA (135 articles) } \\
\text { Molecular Biology, general (1293 articles) }\end{array}$ \\
& \\
\hline
\end{tabular}

